\title{
Differential coupling of bacterial and primary production in mesotrophic and oligotrophic systems of the East China Sea
}

\author{
Fuh-Kwo Shiah" ${ }^{1, *}$, Tzong-Yueh Chen ${ }^{1}$, Gwo-Ching Gong ${ }^{2}$, Chung-Chi Chen ${ }^{3}$, \\ Kuo-Ping Chiang ${ }^{4}$, Jia-Jang Hung ${ }^{5}$
}

\author{
${ }^{1}$ Institute of Oceanography, National Taiwan University, Taipei, Taiwan, ROC \\ ${ }^{2}$ Department of Oceanography, National Taiwan Ocean University, Keeloung, Taiwan, ROC \\ ${ }^{3}$ National Center for Ocean Research, National Taiwan University, Taipei, Taiwan, ROC \\ ${ }^{4}$ Department of Fishery Science, National Taiwan Ocean University, Keeloung, Taiwan, ROC \\ ${ }^{5}$ Institute of Marine Geology and Chemistry, National Sun Yat-Sen University, Kaohsiung, Taiwan, ROC
}

\begin{abstract}
Spatial patterns of integrated bacterial production (IBP; 9 to $179 \mathrm{mg} \mathrm{C} \mathrm{m}^{-2} \mathrm{~d}^{-1}$ ), bacterial biomass (IBB; 125 to $658 \mathrm{mg} \mathrm{C} \mathrm{m}^{-2}$ ), bacterial turnover rates $\left(\mathrm{B} \mu=\mathrm{IBP} / \mathrm{IBB} ; 0.03\right.$ to $\left.0.37 \mathrm{~d}^{-1}\right)$, primary production (IPP; 18 to $2079 \mathrm{mg} \mathrm{C} \mathrm{m}^{-2} \mathrm{~d}^{-1}$ ) and hydrographical variables were measured in the continental shelf of the East China Sea $\left(25.4\right.$ to $31.6^{\circ} \mathrm{N}, 120.5$ to $\left.127.0^{\circ} \mathrm{E}\right)$ during summer and autumn 1998. Sea surface temperatures were $>21^{\circ} \mathrm{C}$ in both seasons. The slopes for $\log _{10} \mathrm{IBP}$ vs $\log _{10} \mathrm{IPP}$ (summer $0.44 \pm 0.09$, autumn 0.52 \pm 0.06 ) and $\log _{10} B \mu$ vs $\log _{10}$ IPP (summer $0.52 \pm 0.06$, autumn 0.50 \pm 0.06 ) were significant with no seasonal difference. IBB showed no trend with IPP. When data were analyzed by separating the study area into the inner- (surface $\mathrm{NO}_{3}>0.25 \mu \mathrm{M}$; mesotrophic) and outer- (surface $\mathrm{NO}_{3}<0.25 \mu \mathrm{M}$; oligotrophic) shelf systems, the slope values of $\log _{10} \mathrm{IBP}$ vs $\log _{10} \mathrm{IPP}$ derived from the inner-shelf (summer $0.48 \pm 0.25,12$ stations; autumn 0.52 $\pm 0.09,16$ stations) data sets were significantly higher than those of the outer-shelf (summer $0.27 \pm 0.13,20$ stations; autumn $0.36 \pm 0.11,26$ stations); there was no difference for the slopes between seasons within each system. Mechanisms causing such differential coupling are not clear since this issue has seldom been addressed before. The results implied that care should be taken when analyzing cross-system or large spatial scale data sets. Our study also revealed that the IBP:IPP ratios (4 to $57 \%$ ) of both seasons showed negative relationships with IPP. Phytoplankton effects on these ratios were dominated concomitantly by algal turnover rate and biomass on the inner-shelf in summer and then shifted to algal biomass dominated over the whole shelf in autumn. Ecological and biogeochemical implications of our findings are discussed.
\end{abstract}

KEY WORDS: Bottom-up control $\cdot$ Continental shelf $\cdot$ Chlorophyll $\cdot$ East China Sea $\cdot$ Heterotrophic bacterioplankton $\cdot$ Inorganic nutrients $\cdot$ Kuroshio $\cdot$ Primary production

Resale or republication not permitted without written consent of the publisher

\section{INTRODUCTION}

Recent studies have suggested that the continental shelves, although comprising $<10 \%$ of the world ocean, may be very important in affecting global carbon cycling due to their large standing stocks of organic carbon as well as high rates of primary pro-

${ }^{*}$ E-mail: fkshiah@ccms.ntu.edu.tw duction (Mantoura et al. 1991, Biscaye et al. 1994, Jickells 1998, Wong et al. 2000). Heterotrophic bacterioplankton are believed to play important roles in regulating accumulation, export, re-mineralization and transformation of the largest organic carbon pool (dissolved organic carbon) in aquatic ecosystems over small (local) and large (global) scales (Cole et al. 1988, Michaels et al. 1994, Hansell \& Carlson 1998, Carlson et al. 1999). In order to understand organic carbon 
cycling and the microbial loop (Pomeroy 1974, Williams 1981, Azam et al. 1983), more detailed studies of which environmental factors regulate bacterial growth and, thus, carbon consumption in different marine provinces are needed.

In aquatic systems, the sources of substrate supply for bacteria may come from phytoplankton exudation, zooplankton sloppy feeding, excretion from other planktoners, release from dead particles and virusinduced lysis (see Ducklow \& Carlson 1992, Fuhrman 1992 for review). In addition, substrates from allochthonous inputs such as river runoff and sediment resuspension also support substantial bacterial growth, particularly in the near-shore systems. Over longer time (seasonal) or spatial (across systems) scales, it has been suggested that primary production is the 'ultimate' factor in controlling bacterial growth (e.g. Cole et al. 1988, Conan et al. 1999 and citations therein), primarily due to the theory that phytoplankton exudation has been considered the most important source of organic substrate in supporting bacterial production. However, organic substrate supply rate from the nonalgal sources mentioned above also co-vary with primary production, indicating that bacteria-phytoplankton coupling might not necessarily be a 'direct' causal relationship. Moreover, up to present, we are still having difficulty quantifying the relative importance of non-biogenic and biogenic components in contributing organic substrate for bacterial production in different ecosystems. The question that needs to be addressed is the complexity of the sources of organic substrate supply in relation to the coupling of bacterial and primary production. Bacteria-phytoplankton coupling might occur due to external controlling factors that affect both bacteria and algae in a similar way (co-variation).

The East China Sea (ECS) has one of the largest shelf systems of the world. Coastal runoff, particularly from the Yantze River (aka The Chiangjiang) plume, has been recognized as having a significant seasonal impact on the ECS shelf, in terms of physical and chemical hydrography as well as sources of inorganic nutrients and dissolved organic matter (Wong et al. 2000 and citations therein). The Three-Gorges Dam is presently under construction in the mid-stream of the Yantze River, and its possible impacts on the biogeochemical cycles in the ECS shelf after it begins to operate in 2009 have been of great concern. Any environmental data collected before its completion in this area may be very useful in evaluating its impacts afterwards. Four seasonal large area field surveys in the ECS shelf have been conducted since December 1997 by Taiwan's Kuroshio Edge Exchange Process project (KEEP; Wong et al. 2000). Here we report on the data collected from the last 2 cruises conducted in summer and autumn 1998.
Several bacterial studies in the ECS have been previously performed, but were limited to cold seasons. Shiah et al. (1999, 2000a,b) suggested that during cold seasons (winter and spring), bacterial growth on the inner-shelf was not limited by substrate supply but by temperature, while on the outer-shelf, the situation was the reverse. Intuitively, one may expect that bacterial growth during warm seasons should be predominately controlled by organic substrate supply over the whole shelf and a positive correlation between bacterial production (and turnover rate) and primary production should be observed. On the other hand, since the runoff of the Yantze River varies dramatically with season, a comparison of the bacteria-phytoplankton relationship during warm periods but with contrasting plume patterns caused by the Yantze River might provide some insight into the study of aquatic microbial ecology. As predicted above, here we show that bacterial production was highly coupled with primary production during warm periods. However, although the magnitude of coupling varied between mesotrophic (the inner-shelf) and oligotrophic (the outer-shelf) systems, the magnitude of coupling seemed to be unchanged between summer and autumn within each system.

\section{MATERIAL AND METHODS}

Study site. Data were collected from the 2 cruises conducted in the continental shelf of the ECS north of Taiwan (Fig. 1) in July (34 stations) and November (32 stations) 1998. Seawater was collected from a SeaBird CTD-General Oceanic Rosette assembly with 201 Go-Flo bottles. Light intensity was measured with a light meter (QSP200L; Biospherical). The depth of the euphotic zone $\left(Z_{\mathrm{e}}\right)$ was defined as $1 \%$ of the surface light level. Surface nitrate concentrations $\left(\mathrm{NO}_{3}\right)$ were used as the boundary of the inner- and outer-shelf stations. For the outer-shelf stations, the surface $\mathrm{NO}_{3}$ concentrations were all $<0.25 \mu \mathrm{M}$, which was the detection limit of our nitrate analysis method (see below). In other words, the inner- and outer-shelf stations were located in eutrophic to mesotrophic and oligotrophic ecosystems, respectively. All of the measurements listed below were taken from the same depth within the $Z_{\mathrm{e}}$ from the same cast.

Bacterial production, abundance and turn-over rates. Bacterial abundance was measured by the acridine orange epifluorescence microscopy (Hobbie et al. 1977) method. Biomass was calculated using a carbon conversion factor of $2 \times 10^{-14} \mathrm{~g} \mathrm{cell}^{-1}$ (Lancelot \& Billen 1984). Bacterial production was estimated by the method of ${ }^{3} \mathrm{H}$-thymidine (Fuhrman \& Azam 1982) incorporation with a conversion factor of $1.18 \times 10^{18}$ cells mol thymidine ${ }^{-1}$ (Cho \& Azam 1988). For details, 


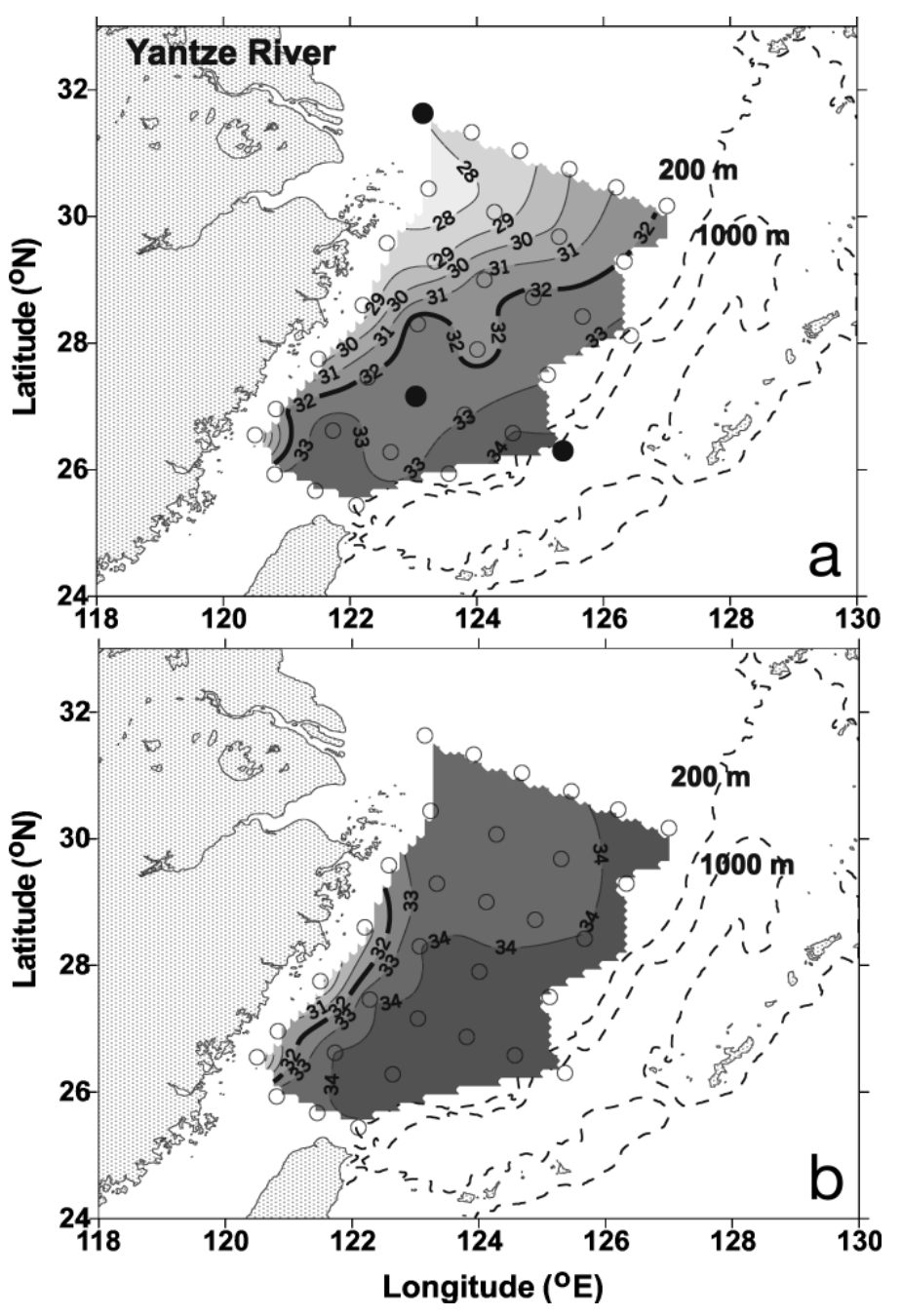

Fig. 1. Contours of surface salinity with sampling stations (O) in the East China Sea of (a) summer and (b) autumn 1998. (-) Substrate enrichment experiment stations are also shown. These experiments were performed on the summer-98 cruise only. Bold lines indicate the isohalines of $32.0 \mathrm{psu}$. Dashed lines indicate bottom depth in meters
July cruise at the 3 stations (Fig. 1a) that represented the inner-, mid- and outer-shelf waters (Table 1). At each station, whole surface water samples were preincubated at in situ (Table 1) and 5 other temperatures ( 5 to $30^{\circ} \mathrm{C}$ ) in $24,2.01$ opaque polycarbonate bottles for $1 \mathrm{~h}$, which was sufficient to allow adjustment to the new temperature. A dissolved free amino acid mixture (DFAA; 15 amino acids, final conc., $0.5 \mu \mathrm{M}$; Shiah et al. 2000b) was added into 12 bottles with duplicates for each temperature treatment after pre-incubation; the remaining 12 unenriched bottles were used as controls. Bacterial production and cell abundance were sampled every 2 to $6 \mathrm{~h}$. The end of the lag period was defined as the time whenever the bacterial production readings in the DFAA treatments were statistically (usually > 20\%) higher than those of the controls.

Primary production. Primary production was measured by the ${ }^{14} \mathrm{C}$ assimilation method (Parsons et al. 1984). In brief, 2 light and 1 dark $250 \mathrm{ml}$, acid cleaned polycarbonate bottles were filled with water samples taken from the $Z_{\mathrm{e}}$. After inoculation with $\mathrm{H}^{14} \mathrm{CO}_{3}$ (final conc., $10 \mu \mathrm{Ci} \mathrm{ml}^{-1}$ ), samples were incubated for 2 to $4 \mathrm{~h}$ in a self-designed tank with an artificial light source. Water temperature was maintained with running seawater. To simulate light intensity, incubation bottles were wrapped with neutral density filters (LEE filters). Following retrieval, the water samples were immediately filtered through Whatman $25 \mathrm{~mm} \mathrm{GF} / F$ filters under low light and low pressure $(<100 \mathrm{~mm} \mathrm{Hg})$. The filters were then placed in scintillation vials, and $0.5 \mathrm{ml}$ of $0.5 \mathrm{~N} \mathrm{HCl}$ was added to remove residual $\mathrm{HCO}_{3}$. Radioactivity was measured in a liquid scintillation counter (Packard 1600) after the addition of $10 \mathrm{ml}$ scintillation cocktail (Ultima Gold, Packard) into the vials. Phytoplankton turnover rate was calculated as depth integrated primary production divided by depth-integrated chlorophyll concentrations with a conversion factor of $58 \mathrm{~g} \mathrm{C} \mathrm{g}^{-1}$ chlorophyll a (chl a) (Eppley et al. 1992). see also Shiah et al. (1999). For each station, triplicate samples were taken from 7 to 11 depths within the $Z_{\mathrm{e}}$. The integrated bacterial biomass (and production) was obtained by integrating (trapezoidal method) over $Z_{\mathrm{e}}$. Bacterial turnover rate $(\mathrm{B} \mu)$ was calculated by dividing integrated bacterial production (IBP) with integrated bacterial biomass (IBB). Note that the conversion factors were not determined empirically and we assumed that they did not change with water mass and season.

Substrate enrichment experiments. Experiments were performed on the
Table 1. List of the in situ values of measured variables for samples used in substrate enrichment experiments in summer 1998

\begin{tabular}{|lcccc|}
\hline Item & Units & $\begin{array}{c}\text { Inner-shelf } \\
\text { waters }\end{array}$ & $\begin{array}{c}\text { Mid-shelf } \\
\text { mixed waters }\end{array}$ & $\begin{array}{c}\text { Outer-shelf } \\
\text { waters }\end{array}$ \\
\hline Temperature & ${ }^{\circ} \mathrm{C}$ & 21 & 27 & 29 \\
Salinity & $\mathrm{psu}$ & 28.03 & 32.57 & 34.21 \\
Nitrate & $\mu \mathrm{M}$ & 12.4 & 0.30 & $<0.25^{\mathrm{a}}$ \\
Euphotic zone depth & $\mathrm{m}$ & 42 & 85 & 95 \\
$\begin{array}{l}\text { Chlorophyll } \\
\text { Primary } \\
\text { production }\end{array}$ & $\mathrm{mg} \mathrm{chl} \mathrm{m}^{-3}$ & 3.93 & 0.21 & 0.11 \\
$\begin{array}{l}\text { Bacterial } \\
\text { production }\end{array}$ & $\mathrm{mg} \mathrm{C} \mathrm{m}^{-3} \mathrm{~d} \mathrm{~d}^{-1}$ & 160.7 & 6.5 & 3.2 \\
a Detection limit & & 5.86 & 1.95 & 0.83 \\
\hline
\end{tabular}


Chl $\boldsymbol{a}$ and nitrate concentrations and data analysis. Chl $a$ and nitrate concentrations were measured following the methods of Parsons et al. (1984). Water samples for nutrient analyses were frozen immediately with liquid nitrogen in clean $100 \mathrm{ml}$ polypropylene bottles. Nitrate was analyzed with a self-designed flow injection analyzer (Gong et al. 1995) and was reduced to nitrite with a cadmium wire, which was activated with a copper sulfate solution. The detection limit of this method was $0.25 \mu \mathrm{M}$. For chl $a, 1$ to 21 of seawater were filtered through $25 \mathrm{~mm}$ Whatman GF/F filters, which were then immediately stored at $-20^{\circ} \mathrm{C}$. Back at the laboratory, the filters were ground in $10 \mathrm{ml} 90 \%$ acetone followed by extraction in a $4{ }^{\circ} \mathrm{C}$ shaking incubator for $2 \mathrm{~h}$. After centrifugation at $1000 \mathrm{rpm}(\sim 200 \times$ $g$ ) for $5 \mathrm{~min}$, the concentrations of chlorophyll in the supernatant were measured on a Turner fluorometer (model 10-AU-005). The StatView $\mathrm{II}^{\mathrm{TM}}$ in Macintosh was used for statistical analysis including linear regression (model 2 for the field data; Sokal \& Rohlf 1969), analysis of variance (ANOVA), analysis of covariance (ANCOVA) and multiple comparisons.

\section{RESULTS}

Seasonal changes in the Yantze River plume (salinity $<32.0 \mathrm{psu}$ ) could be identified by the patterns of sur- face salinity (Fig. 1). In summer, the plume extended to the mid-shelf but in autumn the plume was observed only at a few stations adjacent to the China coast. In both seasons, the ECS shelf was covered with warm seawater with surface temperatures ranging from 21 to 30 and 21 to $27^{\circ} \mathrm{C}$, respectively; sea surface temperatures were colder on the inner-shelf and increased offshore (Fig. 2a). The depths of the euphotic zone were shallower than $10 \mathrm{~m}$ on the inner-shelf and extended down to $90 \mathrm{~m}$ on the outer-shelf. Surface nitrate concentrations $\left(\mathrm{NO}_{3}\right)$ in summer $(<0.2$ to $28.1 \mu \mathrm{M})$ and autumn $(<0.2$ to $24.3 \mu \mathrm{M})$ were high on the inner-shelf and then decreased seawards (Fig. 2b). Note that surface $\mathrm{NO}_{3}$ was depleted at a salinity of 30.0 psu during summer, while that of autumn was still detectable at a salinity of $34.0 \mathrm{psu}$. Surface chl a concentrations (Schl


about 40 -fold, with most of the high values within the inner-shelf. Values of Schl a in autumn dropped to $0.2-2.8 \mathrm{mg} \mathrm{chl} \mathrm{m}^{-3}$ but with the $1.0 \mathrm{mg} \mathrm{chl} \mathrm{m}^{-3}$ isoline extending more toward the mid-shelf (area with salinity of 34 psu; Fig. 2c).

The euphotic zone integrated primary production (IPP; $<20$ to $2080 \mathrm{mg} \mathrm{C} \mathrm{m}^{-2} \mathrm{~d}^{-1}$ ) basically followed the patterns of Schl $a$, with higher values (>1000 $\mathrm{mg} \mathrm{C} \mathrm{m}^{-2} \mathrm{~d}^{-1}$ ) recorded on the inner-shelf during summer. Autumn IPP values over the whole shelf were low, with values similar to the IPP recorded on the outer-shelf in sum-


Fig. 2. Scatter plots of surface values of (a) temperature, (b) nitrate, (c) chlorophyll a, and (d-f) bacterial measurements vs surface salinity for the data derived from summer inner-shelf $(\mathbf{O})$, summer outer-shelf $(\bigcirc)$, autumn inner-shelf $(\star)$ and autumn outershelf $(\hat{z})$ data. Panel (c) is in $\log _{10}$ scale for better presentation 
mer. The values of the euphotic zone IBB (Fig. 2d) and IBP (Fig. 2e) in summer (125 to $658 \mathrm{mg} \mathrm{C} \mathrm{m}^{-2}$ and 22 to $179 \mathrm{mg} \mathrm{C} \mathrm{m}^{-2} \mathrm{~d}^{-1}$ ) were at least $50 \%$ higher than those of autumn (222 to $426 \mathrm{mg} \mathrm{C} \mathrm{m}{ }^{-2}$ and 9 to $70 \mathrm{mg} \mathrm{C}$ $\mathrm{m}^{-2} \mathrm{~d}^{-1}$ ). For both seasons, IBB values were higher and formed dome-shaped patterns outside the Yantze River, and then decreased seawards. For both cruises, there were no significant relationships for IBB vs euphotic zone integrated chlorophyll concentrations

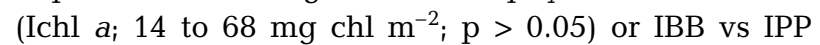
(Fig. 3a).

IBP of summer and autumn showed distinct spatial patterns (Fig. 2e). In summer, IBP was high on the inner-shelf and then decreased seawards; autumn IBP peaked in the mid-shelf (area of $\sim 34.0 \mathrm{psu}$ ) with lower values at both ends. Spatial distribution of $\mathrm{B} \mu$ (Fig. 2f) in summer (0.06 to $0.37 \mathrm{~d}^{-1}$ ) and autumn (0.03 to $0.24 \mathrm{~d}^{-1}$ ) followed the same patterns of their IBP respectively. Both IBP and $\mathrm{B} \mu$ were positively correlated with IPP (Fig. 3b,c) with $\mathrm{R}^{2}$ (coefficient of determination) values $>0.42$ (Table 2). Note particularly that the slopes for $\log _{10}$ IBP vs $\log _{10}$ IPP and $\log _{10} B \mu$ vs $\log _{10}$ IPP calculated from the whole summer and autumn data sets were not significantly different from each other (Table 2). The ranges and averages of IBP:IPP ratio for summer and autumn were 4 to 36 and 4 to $57 \%$ as well as $15 \pm 8$ and $15 \pm 10 \%$, respectively. These ratios showed a negative trend with IPP (Fig. 3d) in both seasons. Further analysis showed that summer $\mathrm{B} \mu$ and IBP:IPP ratio were negative functions of Ichl $a$ and $\mathrm{P} \mu$ (algal turnover rates) simultaneously, while those of autumn were negatively correlated with Ichl a only (Table 2).

The relationships of IBP, B $\mu$ and IBP:IPP ratio vs IPP revealed more interesting information when regional (inner- and outer-shelf systems) differences were considered. For the inner-shelf, the slope values of IBP vs IPP of summer $(0.48 \pm 0.25)$ and autumn $(0.52 \pm 0.09)$ were about $2 \times$ those derived from the outer-shelf $(0.27 \pm 0.13$ and $0.36 \pm 0.13)$. Furthermore, in neither the inner- nor the outer-shelf was there a difference between seasonal slopes (Table 3 ). The relationships for $\mathrm{B} \mu$ vs IPP and IBP:IPP ratio vs IPP were the same as those described above except that the slopes of the latter were negative and higher on the outer-shelf $(-0.72 \pm 0.13$ and $-0.63 \pm 0.11)$ than those of inner-shelf $(-0.52 \pm 0.25$ and $-0.49 \pm 0.09)$ for both seasons.

The in situ conditions for the DFAA enrichment experiments performed at the 3 stations on the summer cruise are listed in Table 1. Dramatic contrasts could be observed among experimental stations, both in terms of chemical and biological measurements. When incubated at in situ temperatures, bacteria responded to the addition of DFAA within $2 \mathrm{~h}$ for the mid- and outershelf samples, while it took a further $2 \mathrm{~h}$ to occur in the inner-shelf samples (Fig. 4). As incubation tempera-



Fig. 3. Scatter plots of (a) depth-integrated bacterial biomass (IBB), (b) production (IBP), (c) turnover rate $(B \mu=I B P / I B B)$ and (d) the ratio of IBP:IPP vs depth-integrated primary production (IPP) for the data derived from summer inner-shelf (O), summer outer-shelf $(\bigcirc)$, autumn inner-shelf $(\star)$ and autumn outershelf $(\hat{\imath})$ data

tures decreased $\left(<20^{\circ} \mathrm{C}\right)$, the lag periods (required for bacteria to respond to the added DFAA) increased in all experiments, indicating that the enrichment effect required a longer time to occur at low temperatures $\left(5\right.$ to $\left.<20^{\circ} \mathrm{C}\right)$.

\section{DISCUSSION AND CONCLUSION}

The continental shelf of the ECS during the warm periods showed strong gradients of inorganic nutrients, algal biomass and primary production. For both seasons, $\mathrm{NO}_{3}$ concentrations were always high on the inner-shelf area (Fig. 2b), but values of Schl a (Fig. 2c) and IPP (Fig. 3a) in autumn were only $50 \%$ of those recorded in summer. Several studies have shown that the Yantze River and the other 7 Chinese rivers that 
Table 2. List of linear regression analysis (model 2) of euphotic zone integrated bacterial measurements (dependent variables) on euphotic zone integrated phytoplankton variable (independent variable). SD: standard deviation; $\mathrm{R}^{2}$ : coefficient of determination; and $n$ : sampling size. Superscripts $(\mathrm{a}-\mathrm{c})$ indicate no difference at $p=0.05$ by ANCOVA. IBP: depth-integrated bacterial production; $\mathrm{B} \mu$ bacterial turnover rate; IPP: depth-integrated primary production; Ichl $a$, depthintegrated chl $a_{\text {; }}$ and $\mathrm{P} \mu$ : phytoplankton turnover rates; ns: non-significant at $\mathrm{p}=0.05$ level; $^{*}$ all significant at $\mathrm{p}=0.05$ level

\begin{tabular}{|c|c|c|c|c|}
\hline & Intercept & Slope $( \pm \mathrm{SD})$ & $\mathrm{R}^{2 *}$ & $\mathrm{n}$ \\
\hline \multicolumn{5}{|c|}{$\log _{10}$ IBP vs $\log _{10}$ IPP } \\
\hline Summer & 0.60 & $0.44( \pm 0.09)^{\mathrm{a}}$ & 0.42 & 32 \\
\hline Autumn & 0.26 & $0.52( \pm 0.06)^{\mathrm{a}}$ & 0.72 & 34 \\
\hline \multicolumn{5}{|c|}{$\log _{10} B \mu$ vs $\log _{10}$ IPP } \\
\hline Summer & -2.21 & $0.52( \pm 0.06)^{\mathrm{b}}$ & 0.71 & 32 \\
\hline Autumn & -2.15 & $0.50( \pm 0.06)^{\mathrm{b}}$ & 0.71 & 34 \\
\hline \multicolumn{5}{|c|}{$\log _{10}$ IBP:IPP vs $\log _{10}$ IPP } \\
\hline Summer & 2.59 & $-0.56( \pm 0.09)^{\mathrm{c}}$ & 0.55 & 32 \\
\hline Autumn & 2.27 & $-0.48( \pm 0.06)^{\mathrm{c}}$ & 0.67 & 34 \\
\hline \multicolumn{5}{|c|}{$\log _{10} B \mu$ vs $\log _{10}$ Ichl $a$} \\
\hline Summer & -1.82 & $0.70( \pm 0.15)$ & 0.44 & 32 \\
\hline Autumn & -1.68 & $0.53( \pm 0.05)$ & 0.76 & 34 \\
\hline \multicolumn{5}{|c|}{$\log _{10} B \mu$ vs $\log _{10} P \mu$} \\
\hline Summer & -0.38 & $0.78( \pm 0.15)$ & 0.50 & 32 \\
\hline Autumn & ns & ns & ns & 34 \\
\hline \multicolumn{5}{|c|}{$\log _{10}$ IBP:IPP vs $\log _{10}$ Ichl $a$} \\
\hline Summer & 2.02 & $-0.64( \pm 0.20)$ & 0.25 & 32 \\
\hline Autumn & 1.75 & $-0.46( \pm 0.07)$ & 0.59 & 34 \\
\hline \multicolumn{5}{|c|}{$\log _{10}$ IBP:IPP vs $\log _{10} P \mu$} \\
\hline Summer & 0.62 & $-0.88( \pm 0.19)$ & 0.44 & 32 \\
\hline Autumn & $\mathrm{ns}$ & $\mathrm{ns}$ & ns & 34 \\
\hline
\end{tabular}

discharge into the ECS shelf are characterized by a high inorganic N/P ratio $\left(\left(\mathrm{NO}_{3}+\mathrm{NO}_{2}\right) / \mathrm{PO}_{4 i}>40 \mathrm{~mol} \mathrm{~N}\right.$ $\mathrm{mol}^{-1} \mathrm{P}$; Wong et al. 2000 and citations therein) and that such imbalances in the N/P ratio might result in $\mathrm{PO}_{4}$-limitation of the growth of phytoplankton (Gong et al. 1996, Wong et al. 1998). Higher Schl a concentrations and IPP observed on the inner-shelf during summer might be due to coastal upwelling induced by the prevalence of the southwest monsoon that increases $\mathrm{PO}_{4}$ availability from the bottom water (Gong et al. 2001). Surface $\mathrm{PO}_{4}$ values on the inner-shelf during summer were above the detection limit $(0.03 \mu \mathrm{M})$, with a mean concentration and N/P ratio of $0.14 \pm 0.14 \mu \mathrm{M}$ and $75 \pm 52 \mathrm{~mol} \mathrm{~N} \mathrm{~mol}^{-1} \mathrm{P}$, respectively. On the other hand, surface $\mathrm{PO}_{4}$ and N/P ratio of the inner-shelf during autumn were $0.46 \pm 0.37 \mu \mathrm{M}$ and $17 \pm 8 \mathrm{~mol} \mathrm{~N}$ $\mathrm{mol}^{-1} \mathrm{P}$, respectively. Higher surface $\mathrm{PO}_{4}$ concentrations on the inner-shelf during autumn might be due to lower values of Schl $a$ and IPP (lower phytoplankton uptake) resulting from low level sunlight intensity (Gong et al. 2001). Note also that the N/P ratios were similar to the Redfield ratio (N/P = 16) during autumn while those for the summer were much higher (N/P ranged from 22 to 167). For the oligotrophic outershelf, $\mathrm{NO}_{3}$ concentrations were low and its availability has been suspected to be the major limiting factor for algal growth (Chen et al. 1999, Chen 2000, Gong et al. $2000,2001)$ since most of the surface $\mathrm{PO}_{4}$ values were still detectable with $\mathrm{N} / \mathrm{P}$ ratios lower $(\mathrm{N} / \mathrm{P}<11)$ than the Redfield ratio.

These results indicate that the innerand outer-shelf were more akin to 2 distinct ecosystems dominated by new and regenerated production, respectively (Chen et al. 1999). Such dissimilarity might result in different phytoplankton species composition with mainly large phytoplankton (diatoms) on the innershelf and small phytoplankton (flagellates) on the outer-shelf (Chiang et al. 1997, Huang et al. 1999, Chen 2000). This implies that care should be taken when analyzing the relationship between bacterial and primary production with large spatial scale data sets. More specifically, the bacteria-phytoplankton relationship might be system-dependent (see discussion below).

Seawater temperatures over the study area were all $>20^{\circ} \mathrm{C}$, which were (or near to) the optimal temperature for the growth of non-hyperthermophilic bacteria (c.f. Wiebe et al. 1992, Shiah et al. 2000b and citations therein). These systems offered a good opportunity to verify the relationship between bacterial growth (particularly turnover rate) and primary production when temperature was not limiting. Although the ranges and spatial patterns of the Yantze River freshwater plume of these 2 cruises were quite distinct, the coupling between bacterial rate parameters (IBP and $\mathrm{B} \mu$ ) and IPP were significant with similar slopes and intercepts when the whole data sets were used in the analysis (Table 2).

Table 3 indicates that after further analysis of our data sets, the magnitude of coupling, as judged from the slope values, could be quite different on the inner- than on the outer-shelf, which represent meso- and oligotrophic systems, respectively. The results revealed that the algal effects on the spatial variability of IBP (and B $\mu$ ) on the inner-shelf were larger (i.e. $2 \times$ ) than those on the outershelf. Such a phenomenon consistently appeared in summer and autumn, although IPP (summer $950 \pm 600$, autumn $292 \pm 231 \mathrm{mg} \mathrm{C} \mathrm{m}^{-2} \mathrm{~d}^{-1}$ ) and $\mathrm{P} \mu$ (summer $0.39 \pm$ 0.10 , autumn $0.19 \pm 0.03 \mathrm{~d}^{-1}$ ) on the inner-shelf changed dramatically within these 2 seasons. Conan et al. (1999, their Table 3) summarized the IBP-IPP relationship from their research, and the research of many others, and found that on an areal basis, the slope values of $\log _{10}$ IBP 
vs $\log _{10}$ IPP were in the range of 0.37 to 0.75 . Our slopes $(0.27$ to 0.52 , Table 3 ) were within but at the lower end of the reported values. The most unique finding of our study that has not been fully addressed previously by many other researchers was that the coupling between bacterial and primary production might be system-dependent.

Several recent studies have demonstrated that phytoplankton species composition, algal exudation capacity (Huang et al. 1999), bacterivory (Sanders et al. 1992) and bacterial community structure might change with different inorganic nutrient status (Lebaron et al. 1999) and seasons (Pinhassi \& Hagrstrom 2000 and citations therein). Vrede (1999) showed that algal species composition could affect bacterial growth. Therefore, the relationship (the slopes) of IBP vs IPP might be expected to deviate substantially by the changes of any of the factors on the inner- and outer-shelf systems. Unfortunately, we have not found any plausible explanation due to the lack of planktonic species composition data.

It is well known that bacterial growth also may be limited by inorganic nutrients such as ammonium $\left(\mathrm{NH}_{4}\right)$ and/or $\mathrm{PO}_{4}$ (Thingstad et al. 1999, Touratier et al. 1999 and citations therein) when the $\mathrm{C} / \mathrm{N}, \mathrm{C} / \mathrm{P}$ or $\mathrm{N} / \mathrm{P}$ ratios of the organic substrate were higher than those of bacteria. A more intriguing idea is that the differential coupling between bacteria and phytoplankton on the inner- and outer-shelf might be regulated by mechanisms independent of the organic substrate control scenario proposed by Cole et al. (1988) and others. That is, bacterial and algal activities might be driven by external sources in a similar manner (co-variation). In enrichment experiments, Shiah (1999) demonstrated that bacterial growth in the surface water samples taken from the outer-shelf (the Kuroshio waters) during summer was not limited by organic carbon (glucose) but by $\mathrm{NH}_{4}$ and/or $\mathrm{PO}_{4}$. His experiments, unfortunately, did not further differentiate which inorganic nutrient was the limiting one. With his and our DFAA experiment results, we suspect that bacterial growth on the outer-shelf was more likely to be limited by nitrogen instead of $\mathrm{PO}_{4}$ for one important reason. If $\mathrm{PO}_{4}$ were the limiting nutrient, then the addition of
Table 3. As in Table 2 but for data sets that were separated into inner- and outershelf areas. Slopes with the same superscripts $(\mathrm{a}-\mathrm{i})$ indicate no difference at $\mathrm{p}=$ 0.05 by ANCOVA

\begin{tabular}{|c|c|c|c|c|c|}
\hline Area & Season & Intercept & Slope $( \pm \mathrm{SD})$ & $\mathrm{R}^{2}$ & $\mathrm{n}$ \\
\hline \multicolumn{6}{|c|}{$\log _{10}$ IBP vs $\log _{10}$ IPP } \\
\hline \multirow[t]{2}{*}{ Inner-shelf } & Summer & 0.49 & $0.48( \pm 0.25)^{\mathrm{a}}$ & 0.27 & 12 \\
\hline & Autumn & 0.23 & $0.52( \pm 0.09)^{\mathrm{a}}$ & 0.72 & 16 \\
\hline \multirow[t]{2}{*}{ Outer-shelf } & Summer & 0.98 & $0.27( \pm 0.13)^{\mathrm{b}}$ & 0.20 & 20 \\
\hline & Autumn & 0.70 & $0.36( \pm 0.11)^{b}$ & 0.76 & 16 \\
\hline \multicolumn{6}{|c|}{$\log _{10} B \mu$ vs $\log _{10}$ IPP } \\
\hline \multirow[t]{2}{*}{ Inner-shelf } & Summer & -2.27 & $0.56( \pm 0.08)^{\mathrm{c}}$ & 0.83 & 12 \\
\hline & Autumn & -2.25 & $0.53( \pm 0.08)^{\mathrm{c}}$ & 0.77 & 16 \\
\hline \multirow[t]{2}{*}{ Outer-shelf } & Summer & -1.63 & $0.28( \pm 0.10)^{\mathrm{d}}$ & 0.30 & 20 \\
\hline & Autumn & -1.44 & $0.24( \pm 0.10)^{\mathrm{d}}$ & 0.30 & 16 \\
\hline \multicolumn{6}{|c|}{$\log _{10}$ IBP:IPP vs $\log _{10}$ IPP } \\
\hline \multirow[t]{2}{*}{ Inner-shelf } & Summer & 2.49 & $-0.52( \pm 0.25)^{\mathrm{e}}$ & 0.30 & 12 \\
\hline & Autumn & 2.26 & $-0.49( \pm 0.09)^{\mathrm{e}}$ & 0.69 & 16 \\
\hline \multirow[t]{2}{*}{ Outer-shelf } & Summer & 2.97 & $-0.72( \pm 0.13)^{\mathrm{f}}$ & 0.64 & 20 \\
\hline & Autumn & 2.70 & $-0.63( \pm 0.11)^{\mathrm{f}}$ & 0.72 & 16 \\
\hline \multicolumn{6}{|c|}{$\log _{10} B \mu$ vs $\log _{10}$ Ichl a } \\
\hline \multirow[t]{2}{*}{ Inner-shelf } & Summer & -1.50 & $0.57( \pm 0.15)^{g}$ & 0.60 & 12 \\
\hline & Autumn & -1.72 & $0.54( \pm 0.08)^{g}$ & 0.78 & 16 \\
\hline \multirow[t]{2}{*}{ Outer-shelf } & Summer & -1.51 & $0.44( \pm 0.15)^{g}$ & 0.37 & 20 \\
\hline & Autumn & -1.33 & $0.32( \pm 0.10)^{g}$ & 0.41 & 16 \\
\hline \multicolumn{6}{|c|}{$\log _{10} B \mu$ vs $\log _{10} P \mu$} \\
\hline \multirow[t]{2}{*}{ Inner-shelf } & Summer & -0.25 & $0.93( \pm 0.39)$ & 0.39 & 12 \\
\hline & Autumn & ns & ns & ns & 16 \\
\hline \multirow[t]{2}{*}{ Outer-shelf } & Summer & ns & ns & ns & 20 \\
\hline & Autumn & ns & ns & ns & 16 \\
\hline \multicolumn{6}{|c|}{$\log _{10}$ IBP:IPP vs $\log _{10}$ Ichl $a$} \\
\hline \multirow[t]{2}{*}{ Inner-shelf } & Summer & ns & ns & ns & 12 \\
\hline & Autumn & 1.76 & $-0.50( \pm 0.09)^{\mathrm{h}}$ & 0.68 & 16 \\
\hline \multirow[t]{2}{*}{ Outer-shelf } & Summer & 2.55 & $-0.99( \pm 0.24)$ & 0.49 & 20 \\
\hline & Autumn & 1.96 & $-0.57( \pm 0.16)^{\mathrm{h}}$ & 0.48 & 16 \\
\hline \multicolumn{6}{|c|}{$\log _{10}$ IBP:IPP vs $\log _{10} P \mu$} \\
\hline \multirow[t]{2}{*}{ Inner-shelf } & Summer & 0.31 & $-1.65( \pm 0.49)$ & 0.56 & 12 \\
\hline & Autumn & ns & ns & ns & 16 \\
\hline \multirow[t]{2}{*}{ Outer-shelf } & Summer & ns & ns & ns & 20 \\
\hline & Autumn & ns & ns & ns & 16 \\
\hline
\end{tabular}

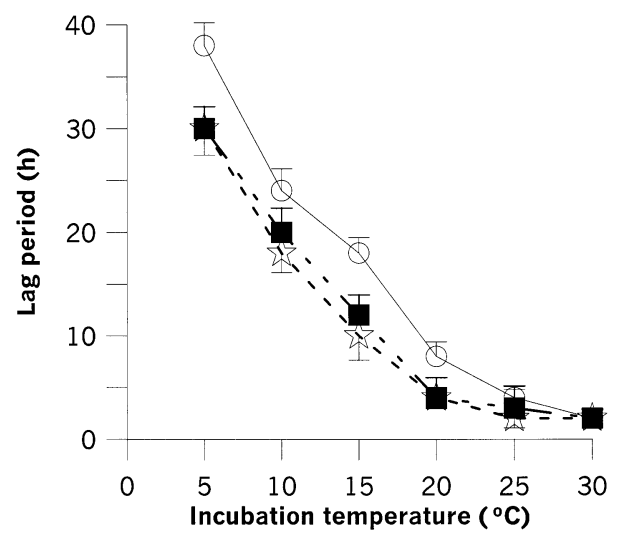

Fig. 4. Lag period required for bacteria to respond to the enrichment of dissolved free amino acids at different temperatures. Experiments were performed in summer 1998 using samples taken from the inner- $(\bigcirc)$, the mid- $(\square)$ and the outershelf $(\hat{\imath})$ 
DFAA (which contained no P) would not enhance bacterial growth. The low inorganic N/P ratios observed on the outer-shelf suggested that algal growth might be limited by inorganic nitrogen. It is very likely that inorganic nitrogen, particularly $\mathrm{NH}_{4}$ availability, was the limiting factor in regulating the spatial variability of bacteria and phytoplankton growth simultaneously on the outer-shelf. The system becomes more oligotrophic as one moves from the mid- to the outer-shelf, and both IBP and IPP decrease due to reducing $\mathrm{NH}_{4}$ availability, which results in a positive relationship of IBP and IPP. Meanwhile, bacteria are more competitive for $\mathrm{NH}_{4}$ uptake due to their much larger surface to volume ratio than phytoplankton (Bratbak \& Thingstad 1985), and this might lead to a higher IBP:IPP ratio in a lower IPP area.

On the other hand, inorganic nutrient limitation on bacterial growth on the inner-shelf seemed to be less likely due to copious $\mathrm{NH}_{4}$ (0.34 to $1.31 \mu \mathrm{M}$; Liean 1999) and $\mathrm{PO}_{4}$ (summer $0.14 \pm 0.14 \mu \mathrm{M}$; autumn $0.46 \pm$ $0.37 \mu \mathrm{M})$ in the surface waters. Dissolved organic carbon (DOC) concentrations in this area were high (85 to $120 \mu \mathrm{M}$ ) in the Yantze River plume and decreased seawards to concentrations of $<70 \mu \mathrm{M}$ (Hung et al. 2001). DOC degradation rate for the coastal waters was about $0.05 \mathrm{~d}^{-1}$, suggesting that some portions of riverine DOC were labile to semi-labile (Hung et al. 2001). The DFAA enhancement effect on the coastal waters might be due to the addition of organic nitrogen instead of organic carbon. In these experiments, the lag periods of the inner-shelf samples (Fig. 4$)$ were about $2 \times(4 \mathrm{~h})$ longer than those of the mid- and outer-shelf samples, while the lag periods of the latter 2 samples showed no difference from each other ( $t$-test, $\mathrm{p}>0.05, \mathrm{n}=6)$. This implied that the strength of bottom-up control probably was weaker in the inner-shelf (Sanders et al. 1992), where surface chlorophyll (3.9 $\left.\mathrm{mg} \mathrm{chl} \mathrm{m}^{-3}\right)$ and primary production (161 $\mathrm{mg} \mathrm{C} \mathrm{m}^{-3} \mathrm{~d}^{-1}$ ) were at least $10 \times$ higher than those of the other 2 areas (Table 1). Another possibility, as stated above, was that the in situ temperature of the inner-shelf sample $\left(21^{\circ} \mathrm{C}\right)$ was lower than those of the mid- and outer-shelf $\left(27\right.$ to $\left.29^{\circ} \mathrm{C}\right)$ samples.

As for bacterial biomass, no correlation was observed for IBB vs IPP. This suggests that processes other than substrate supply, such as bacterivory (Fuhrman \& McManus 1984, Sherr et al. 1987, Sanders et al. 1992) and viral lysis (Proctor \& Fuhrman 1990, 1991), could be important in regulating the spatial pattern of IBB. This is consistent with the conclusion of Ducklow (1999) that bacterial biomass and production might be independently regulated by different processes. Fig. 2d shows that in the low salinity (<33.5 psu) area, summer bacteria biomass (370 \pm $164 \mathrm{mg} \mathrm{C} \mathrm{m}^{-2}$ ) was slightly higher than that of autumn $\left(306 \pm 52 \mathrm{mg} \mathrm{C} \mathrm{m}^{-2}\right)$, indicating that there might be more riverine bacteria imported into the shelf by the Yantze River plume during summer. Note that the IBP recorded on the inner-shelf during summer $(88 \pm 46$ $\left.\mathrm{mg} \mathrm{C} \mathrm{m} \mathrm{C}^{-2} \mathrm{~d}^{-1}\right)$ was about $2.7 \times$ that of autumn $(33 \pm 18$ $\mathrm{mg} \mathrm{C} \mathrm{m} \mathrm{m}^{-2} \mathrm{~d}^{-1}$ ) while IBB of the former was only $21 \%$ higher than that of the latter. The abundance of heterotrophic ciliates (Lin 2000) recorded on the innershelf during summer $\left(40\right.$ to $60 \times 10^{4}$ cells m${ }^{-3}$ ) was at least $4 \times$ higher than that of the autumn ( 5 to $15 \times 10^{4}$ cells $\left.\mathrm{m}^{-3}\right)$, indicating the possibility of higher ciliate grazing pressure on IBB during summer. In addition, abundant ciliate numbers imply that there might be higher organic substrate flux from ciliates in supporting higher $\mathrm{B} \mu$ (Nagata \& Kirchman 1992) on the inner-shelf during summer than in autumn.

Although the slope values B $\mu$ vs IPP (= Ichl $a \times P \mu)$ were similar between summer and autumn within each system, Table 3 reveals more subtle information with regard to their relationship. The spatial variation of $\mathrm{B} \mu$ derived from different systems and seasons were always related to the changes of Ichl $a$ instead of $\mathrm{P} \mu$, with 1 exception. Note that $\mathrm{P} \mu$ on the inner-shelf during summer $(0.39 \pm 0.10)$ was about $2 \times$ higher than those recorded on the inner-shelf during autumn $(0.19 \pm 0.03$ $\left.\mathrm{d}^{-1}\right)$, the outer-shelf during summer $\left(0.23 \pm 0.07 \mathrm{~d}^{-1}\right)$ and the outer-shelf during autumn $\left(0.18 \pm 0.04 \mathrm{~d}^{-1}\right)$. This indicates that $\mathrm{P} \mu$ effects on $\mathrm{B} \mu$ occurred only in the system when $\mathrm{P} \mu$ was high (see also below).

Ratios of IBP:IPP varied 4 to $57 \%$ for both cruises, with an overall average of $15 \pm 9 \%$. These values were somewhat lower than, but still within the range of, a review paper of oceanic IBP:IPP ratio $(25 \%)$ presented by Ducklow (1999). In a study conducted in the NW Mediterranean Sea, Conan et al. (1999) found that the relationship between IBP:IPP ratio and chlorophyll normalized primary production $(\mathrm{PE}=\mathrm{IPP} / \mathrm{Ichl} a$, an index of $\mathrm{P} \mu$ ) could be expressed as a power function of $(\mathrm{IBP} / \mathrm{IPP})$ ratio $=25.1 \times \mathrm{PE}^{-0.68}$. In addition, for a large range of $\mathrm{PE}>1.0 \mathrm{~g} \mathrm{C} \mathrm{g}^{-1} \mathrm{chl} \mathrm{h}^{-1}\left(=0.21 \mathrm{~d}^{-1}\right.$ of $\mathrm{P} \mu$ of this study), the ratio remained low $(<25 \%)$, but increased dramatically for lower values of PE. Our summer innershelf data coincided with their observation but further showed that Ichl a also plays a role in affecting the variation of IBP:IPP ratio (Table 3). This suggests that phytoplankton effects on IBP:IPP ratio might be mediated through either algal biomass, turnover rate controls or both, and that such controls might shift between seasons and systems. As mentioned above, $\mathrm{P} \mu$ on the inner-shelf during summer were high $(0.23$ to $0.57 \mathrm{~d}^{-1}$ ) while most of (40 out of 51 ) the $\mathrm{P} \mu$ values derived from the other seasons and systems were $<0.23 \mathrm{~d}^{-1}$. It was suspected that algal turnover rate control on IBP:IPP ratio might occur only when P $\mu$ was high, such as in the case of Conan's et al. (1999) study and our summer inner-shelf data. On the other hand, 
when $\mathrm{P} \mu$ values were low, algal biomass control on the spatial variation of IBP:IPP ratio probably would be more important. The same kind of argument could probably also be applied to the relationships for Ichl $a$ and $\mathrm{P} \mu$ on $\mathrm{B} \mu$ (Table 3 ).

The negative relationship between IBP:IPP ratios and IPP has been observed in the cold Southern Ocean $\left(<3^{\circ} \mathrm{C}_{i} 47\right.$ to $60^{\circ} \mathrm{S}$, Lochte et al. 1997 , their Fig. 8b). Such a phenomenon was ascribed to the uncoupling or time lag between phytoplankton and bacteria development. Lochte et al. (1997) proposed several possible scenarios as an explanation, which included extremely low exudation rate of DOC by phytoplankton, low bacterial uptake or conversion of organic material, and repression of bacterial metabolism due to low temperatures or high grazing pressure. In our study, the low temperature scenario seemed not to be the case since water temperatures were all $>21^{\circ} \mathrm{C}$ during study periods and no correlation was observed for summer $(\mathrm{n}=34)$ and autumn (n = 32) IBP:IPP ratios vs water temperatures or salinity ( $p>$ 0.05). Nevertheless, our data could not verify any of the other explanations but do document comparative findings in a very distinct ecosystem (i.e. temperate-subtropical). In fact, uncoupling (between phytoplankton and bacteria) is a phenomenon that has been observed through time-series study only (e.g. Ducklow 1999, his Figs. 2, 3 \& 5). Our investigations were conducted in a way to address spatial variation. Nevertheless, from the organic carbon cycling point of view, as suggested by Conan et al. (1999), a high IBP:IPP ratio may lead to a consequence that there may be less material available for higher trophic level and/or for export to the deep ocean and sediments.

In summary, inorganic nutrient, phytoplankton biomass and production showed strong gradients in the continental shelf of the ECS during warm seasons with high seasonal contrast in the spatial patterns of the Yantze River plume. High seawater temperature $\left(>21^{\circ} \mathrm{C}\right)$ seemed to be the ultimate factor driving bacterial growth, which was strongly coupled to primary production over the ECS shelf. However, our major finding that has not been fully addressed before suggests that algal effects on bacterial rate parameters might be system-dependent, as indicated by the different slopes for IBP (and B $\mu$ ) vs IPP from the inner- and outer-shelf systems. This implies that care should be taken in analyzing cross-system data sets derived from large spatial scale studies. Our study further indicates that phytoplankton effects on bacterial turnover rate might be concomitantly via algal biomass and turnover rate control on the inner-shelf in summer, and via algal biomass control on the outer-shelf in summer and over the whole shelf in autumn. The phenomena derived from the inner-shelf during warm seasons are quite different from previous studies (Shiah et al. 1999, 2000b) performed in the same area during cold seasons, stating that temperature was the major limiting factor in controlling bacterial spatial variation. This suggests that temperature, organic substrate and inorganic nutrient controls on bacterial growth in the ECS shelf might switch among locations within season and among seasons. The IBP:IPP ratios $(15 \pm 9 \%)$ recorded from this study are in the range of reported values of the world ocean. The negative correlation between IBP:IPP ratios and IPP has been reported in several ecosystems, but its ecological implications are not very clear and must be further explored.

Acknowledgements. Support for this research was provided by the National Science Council, Taiwan. Cruise assistance from the crew of the RV 'Ocean Researcher I' and the valuable comments from 2 anonymous reviewers are deeply appreciated.

\section{LITERATURE CITED}

Azam F, Fenchel T, Field JG, Gray JS, Meyer-Reil LA, Thingstad F (1983) The ecological role of water-column microbes in the sea. Mar Ecol Prog Ser 10:257-263

Biscaye PE, Flagg CN, Falkowski PG (1994) The shelf-edge exchanges processes experiment, SEEP-II: an introduction to hypotheses, results and conclusions. Deep-Sea Res 41(2/3):231-252

Bratbak G, Thingstad TF (1985) Phytoplankton-bacteria interactions: an apparent paradox? Analysis of a model system with both competition and commensalism. Mar Ecol Prog Ser 25:23-30

Carlson CA, Bates NR, Hansell DA, Ducklow HW (1999) Estimation of bacterial respiration and growth efficiency in the Ross Sea, Antarctica. Aquat Microb Ecol 19:229-244

Chen LYL (2000) Comparisons of primary productivity and phytoplankton size structure in the marginal regions of southern East China Sea. Cont Shelf Res 20(4/5):437-458

Chen LYL, Lu HB, Shiah FK, Gong GC, Liu KK, Kanda J (1999) New production and F-ratio on the continental shelf of the East China Sea: comparisons between nitrate inputs from the subsurface Kuroshio Current and the Chiangjiang River. Estuar Coast Shelf Sci 48:59-75

Chiang KP, Shiah FK, Gong GC (1997) Distribution of summer diatom assemblages in and around a local upwelling in the East China Sea northeast of Taiwan. Bot Bull Acad Sin 38:121-129

Cho BC, Azam F (1988) Major role of bacteria in biogeochemical fluxes in the ocean's interior. Nature 332:441-443

Cole JJ, Findlay S, Pace ML (1988) Bacterial production in fresh and saltwater ecosystems: a cross-system overview. Mar Ecol Prog Ser 43:1-10

Conan P, Turley C, Stutt E, Pujo-Pay M, Van Wambeke F (1999) Relationship between phytoplankton efficiency and the proportion of bacterial production to primary production in the Mediterranean Sea. Aquat Microb Ecol 17: 131-144

Ducklow HW (1999) The bacterial content of the ocean euphotic zone. FEMS Microbiol Ecol 30:1-10

Ducklow HW, Carlson CA (1992) Oceanic bacterial production. In: Marshall KC (ed) Advance in microbial ecology. Plenum Press, New York, p 113-181

Eppley RW, Chavez FP, Barber RT (1992) Standing stocks of particulate carbon and nitrogen in the equatorial Pacific at $150^{\circ}$ W. J Geophys Res 97(C1):655-661 
Fuhrman JA (1992) Bacterioplankton roles in cycling of organic matter: the microbial food web. In: Falkowski PG, Woodhead AD (eds) Primary productivity and biogeochemical cycles in the sea. Plenum Press, New York, p 361-383

Fuhrman JA, Azam F (1982) Thymidine incorporation as a measurement of heterotrophic bacterioplankton production in marine surface waters: evaluation and field results. Mar Biol 66:109-120

Fuhrman JA, McManus GB (1984) Do bacteria-sized marine eukaryotes consume significant bacterial production? Science 224:1257-1260

Gong GC, Liu KK, Pai SJ (1995) Prediction of nitrate concentration from two end member mixing in the Southern East China Sea. Cont Shelf Res 15:827-842

Gong GC, Chen LYL, Liu KK (1996) Chemical hydrography and chlorophyll distribution in the East China Sea during summer: implications in nutrient dynamics. Cont Shelf Res 16:1561-1590

Gong GC, Shiah FK, Liu KK, Wen YH, Liang MH (2000) Spatial and temporal variation of chlorophyll a, primary productivity and chemical hydrography in the southern East China Sea during summer: implications in nutrient dynamics. Cont Shelf Res 20(4/5):411-436

Gong GC, Wen YH, Wang BW, Liu GJ (2001) Seasonal variation of chlorophyll a concentration, primary production and environmental conditions in the subtropical East China Sea: prior to the operation of the Three-Gorges Dam. Deep-Sea Res (in press)

Hansell DA, Carlson CA (1998) Deep-ocean gradients in the concentration of dissolved organic carbon. Nature 395: 263-266

Hobbie JE, Daley RJ, Jasper S (1977) Use of nuclepore filters for counting bacteria by fluorescence microscopy. Appl Environ Microbiol 33(5):1225-1228

Huang B, Hong H, Wang H (1999) Size fractionated primary productivity and the phytoplankton-bacteria relationship in the Taiwan Strait. Mar Ecol Prog Ser 183:29-38

Hung JJ, Chen CH, Gong GC, Sheu DD, Shiah FK (2001) Distribution, stoichiometric patterns of dissolved organic matter in the East China Sea and their cross-shelf export. Deep-Sea Res (in press)

Jickells TD (1998) Nutrient biogeochemistry in the coastal zone. Science 281:217-222

Lancelot C, Billen G (1984) Activity of heterotrophic bacteria and its coupling to primary production during the spring phytoplankton bloom in the south bight of the North Sea. Limnol Oceanogr 29(4):721-730

Lebaron P, Servais P, Troussellier M, Courties C, Vives-Rego J, Muyzer G, Benard L, Guindulain T, Schafer H, Stackebrandt $\mathrm{E}$ (1999) Changes in bacterial community structure in seawater mesocosms differing in their nutrient status. Aquat Microb Ecol 19:255-267

Liean CH (1999) Temporal and spatial variability of ammonium concentrations and its uptake by different size phytoplankton in the East China Sea. Master thesis, Institute of Marine Biology, Nationall Sun Yat-Sen University

Lin CY (2000) Studies on temporal and spatial variations of the abundance of oligotrich ciliates in the East China Sea. Master thesis, Dept Fishery Science, National Taiwan Ocean University

Lochte K, Bjonrsen PK, Giesenhagen H, Weber A (1997) Bacterial standing stock and production and their relationship to phytoplankton in the Southern Ocean. Deep-Sea Res II 44(1-2):321-340

Editorial responsibility: Patricia Glibert,

Cambridge, Maryland, USA
Mantoura RFC, Martin JM, Wollast R (1991) Ocean processes in global change. Wiley \& Sons, New York

Michaels AF, Bates NR, Buesseler KO, Carlson CA, Knap AH (1994) Carbon-cycle imbalance in the Sargasso Sea. Nature 372:537-539

Nagata T, Kirchman DL (1992) Release of organic matter by heterotrophic protozoa: implication for microbial foodwebs. Arch Hydrobiol 35:99-109

Parsons TR, Maita Y, Lalli CM (1984) A manual of chemical and biological methods for seawater analysis. Pergamon, New York

Pinhassi J, Hagrstrom K (2000) Seasonal sucession of marine bacterioplankton. Aquat Microb Ecol 21(3):245-256

Pomeroy LR (1974) The ocean's foodweb, a changing paradigm. BioScience 24(7):499-504

Proctor LM, Fuhrman JA (1990) Viral mortality of marine bacteria and cyanobacteria. Nature 343(4):60-62

Proctor LM, Fuhrman JA (1991) Roles of viral infection in organic particle flux. Mar Ecol Prog Ser 69:133-142

Sanders RW, Caron DA, Berninger U (1992) Relationships between bacteria and heterotrophic nanoplankton in marine and fresh waters: an inter-ecosystem comparison. Mar Ecol Prog Ser 86:1-14

Sherr EB, Sherr BF, Albright LJ (1987) Bacteria: link or sink. Science 235:88-89

Shiah FK (1999) Diel cycles of heterotrophic bacterioplankton abundance and production in the ocean surface waters. Aquat Microb Ecol 17(3):239-246

Shiah FK, Gong GC, Liu KK (1999) Temperature vs substrate limitation of heterotrophic bacterioplankton production across trophic and temperature gradient in the East China Sea. Aquat Microb Ecol 17(3):247-254

Shiah FK, Liu KK, Kao SJ, Gong GC (2000a) The coupling of bacterial production and hydrography in the southern East China Sea. Cont Shelf Res 20(4/5):459-477

Shiah FK, Gong GC, Chen TY, Chen CC (2000b) Temperature dependence of bacterial specific growth rates on the continental shelf of the East China Sea and its potential application in estimating bacterial production. Aquat Microb Ecol 22(2):155-162

Sokal RR, Rohlf FJ (1969) Biometry: the application and practice of statistics in biological research. Freeman \& Company, San Francisco

Thingstad TF, Perez M, Pelegri S, Dolan J, Rassoulzadegan F (1999) Trophic control of bacterial growth in microcosms containing a natural community from northwest Mediterrean surface waters. Aquat Microb Ecol 18:145-156

Touratier F, Legendre L Vezina A (1999) Model of bacterial growth influenced by substrate $\mathrm{C}: \mathrm{N}$ ratio and concentrations. Aquat Microb Ecol 19:105-118

Vrede K (1999) Effects of inorganic nutrients and zooplankton on the growth of heterotrophic bacterioplankton - enclosure experiments in an oligotrophic clear water lake. Aquat Microb Ecol 18(2):133-134

Wiebe WJ, Sheldon WM, Pomeroy LR (1992) Bacterial growth in the cold: evidence for an enhanced substrate requirement. Appl Environ Microbiol 58(1):359-364

Williams PJLeB (1981) Incorporation of microheterotrophic processes into the classical paradigm of the planktonic food web. Kiel Meeresforsch 5:1-28

Wong GTF, Gong GC, Liu KK, Pai SJ (1998) 'Excess Nitrate' in the East China Sea. Estuar Coast Shelf Sci 46:411-418

Wong GTF, Chao SY, Li YH, Shiah FK (2000) The Kuroshio Exchange Processes (KEEP) - an introduction to hypotheses and highlights. Cont Shelf Res 20(4/5):335-347

Submitted: August 1, 2000; Accepted: December 20, 2000

Proofs received from author(s): February 9, 2001 